\title{
Predicting financial distress in the Indian textile sector DOI: 10.35530/IT.072.05.20214
}

RASHMI RUPESH SONI

RAMONA BIRAU

IQBAL THONSE HAWALDAR

ELENA LOREDANA MINEA

ANJU SUNNY VASWANI

SUHAN MENDON

CRISTI SPULBAR

MARIA MAGDALENA CRIVEANU

\section{ABSTRACT - REZUMAT}

\section{Predicting financial distress in the Indian textile sector}

The purpose of this paper is to predict the financial distress of companies of the Indian textile sector using Altman Z score. The analysis conducted on 161 listed textile companies in India for a period of 10 years from 2009 to 2018 . All the listed companies are categorized into large, medium, and small using the median split method based on the size of total assets. Kruskal Wallis test is applied to test whether the mean z-score is different for each category of companies. This research study shows that majority of the companies in the Indian textile sector are facing financial distress. Further, it shows that the z score of small, medium, and large-scale textile companies in India is significantly different.

Keywords: textile sector, performance, Altman Z score, bankruptcy, discriminant analysis, financial investment, customer

\section{Predicția distresului financiar în cazul sectorului textil din India}

Obiectivul acestui articol de cercetare este de a previziona distresul financiar al companiilor din sectorul textil indian folosind modelul Scorului Z a lui Altman. Analiza a fost efectuată la nivelul a 161 de companii din sectorul textil, listate pe piața bursieră din India pentru o perioadă de 10 ani, respectiv din 2009 până în 2018. Toate companiile listate sunt clasificate în mari, medii și mici, utilizând metoda divizării mediane bazată pe mărimea activelor totale. Testul Kruskal Wallis este aplicat pentru a testa dacă scorul mediu Z este diferit pentru fiecare categorie de companii. Acest studiu de cercetare demonstrează că majoritatea companiilor din sectorul textil indian se confruntă cu probleme financiare. Mai mult, arată că scorul Z al companiilor mici, mijlocii și mari din sectorul textil din India, este semnificativ diferit.

Cuvinte cheie: sectorul textil, performanță, scor Altman Z, faliment, analiză discriminantă, investiție financiară, consumator

\section{INTRODUCTION}

The textile sector is one of the oldest sectors in India and the contribution of the sector in the Indian economy is remarkable. It employs more than 45 million skilled and unskilled labour. The industry contributes $2 \%$ to GDP of the economy and $15 \%$ to export earnings of India in the fiscal year ended 2017-18. However, the recent insolvency cases registered with NCTL of textile companies like Alok Industries Ltd., Reid and Taylor India Ltd., Mandhana Industries, and Provogue India Ltd. are indeed alarming, and it becomes important to know the risk involved in the sector. Alok Industries alone has defaulted on a loan of as high as Rs. 29,500 crores (based on Indian numbering system). The overall sector also saw a major hit due to GST implementation and demonetization. The current study is an attempt to predict the bankruptcy of 161 listed companies in the Indian textile sector. It further attempts to find the relationship of selected financial ratios and $Z$ score.

Financial distress is the inability of the company to fulfil its debt obligations which ultimately can lead to bankruptcy. If the financial distress can be predicted in advance using such models, then huge losses can be avoided by taking appropriate steps. With the use of business failure prediction models, companies have got warning signals and can lower their chances of going into bankruptcy.

The Z-Score bankruptcy model was developed by Edward Altman in 1968 [1]. Altman tested the predictive power of 22 financial ratios using multiple discriminant analysis and finalized five specific ratios to predict the financial distress of the companies. The ratios like Profitability ratio, Liquidity ratio, Productivity ratio, leverage ratio, and asset turnover ratio were found to have the greatest predictive power to forecast bankruptcy.

The $z$ score is computed using the following equation:

$$
Z=1.2 \times 1+1.4 \times 2+3.3 \times 3+0.6 \times 4+0.999 \times 5
$$

where $x 1$ is Working Capital/Total Assets, $x 2$ Retained Earnings/Total Assets, $x 3$ - Earnings before Interest and Taxes/Total Assets; $x 4$ - Market Capitalization/Total Liabilities; $x 5$ - Sales/Total Assets. 


\section{LITERATURE REVIEW}

The empirical research on bankruptcy prediction is varied and large. Beaver used a univariate discriminant analysis to study the ratios of bankrupt and nonbankrupt firms [2]. After his initial work, many bankruptcy prediction models are developed and tested by researchers. The most renowned research in this area is proposed by Altman [1]. He employed multiple discriminant analysis (MDA) to identify bankruptcy prediction ratios. Moreover, contagion represents an unpredictable propagation of shocks [3]. Some other researchers [4] highlighted the fact that volatility does not diverge to infinity, but it is is influenced differently considering high positive or high negative stock market returns. Later, a similar technique was used by researchers such as: Grice and Ingram [5], Agarwal and Taffler [6], but also Batchelor [7]. Moreover, Ullal et al. [8] suggested that Indian customers are more emotional. Significant work in MDA is also done by Springate [9] and Fulmer et al. [10] who developed their bankruptcy models. On the other hand, Ohlson [11] argued that assumptions about multivariate normality and independence of predictor variables of MDA are restrictive. Thus, he proposed a new model based on logit Regression analysis taking into consideration nine accounting ratios. Similar work is done by Campbell et al. [12], Sun et al. [13], Jones et al. [14]. Zmijewski [15] used a probit analysis to develop a bankruptcy prediction model. The difference between logit and probit analysis is that the later assume normal distribution of independent variables in the model. His model was further tested by authors like Wu et al. [16]. For instance, Meher et al. [17] suggested that due to the global financial crisis of 2008 the whole banking sector of India was under deep stress because of NonPerforming Assets (NPA). Mehdiabadi et al. [18] argued that global economy is constantly changing so it is very important to consider innovation and technological development as main factors in order to achieve a sustainable growth. Moreover, Meher et al. [19] suggested that considering the ongoing dynamics it is more preferable for India, which is an emerging country, to be an active part of the digitization process. In the Asian context in general and Indian context, many researchers have applied the Altman Z score and other models to predict bankruptcy of varied sectors. Bandyopadhyay [20] evaluated the default probability of Indian corporate bonds using logit analysis. Mishra [21] performed the credit risk evaluation of BSE 200 companies and found that 63.6 percent of the original grouped companies are correctly classified using the Z score model. Patanwala [22] examined the financial distress among the major players in the FMCG sector using Altman's Z-Score. Sanesh [23] assessed the Altman Z-score of NIFTY 50 companies excluding banks and financial companies. It was found that most companies are in a safe zone and 9 companies are in the grey zone and 5 companies are in danger zone. Malik et al. [24] analysed the Textile sector of
Pakistan using a $z$ score. The study concluded that the textile industry of Pakistan failed to survive in the international market during the crisis period (2007-2009) and in the recovery period (2010-2012), financial health was found to be comparatively better. Archana [25] predicted the z-score of selected retail firms in India. Rim and Roy [7] applied the Altman Z score to evaluate Lebanon companies and found that it is a sound tool to predict financial distress. Batchelor [8] tested the efficacy of Altman Z-score and concluded that manipulating variables of the Altman Z-score yields better results. Altman [26] tested the prediction accuracy of the original Altman $Z$ score in the international context and concluded that the model works well in most of the countries.

In the backdrop of such findings in the literature, the current study has emphasized on Altman Z score over the other bankruptcy models. Further, very few studies are conducted on the textile sector in general and the Indian textile sector in specific. Thus, the current study attempts to predict bankruptcy in the Indian textile sector.

\section{RESEARCH ANALYSIS}

In the financial domain, where wealth multiplication is involved, the most vulnerable players are the investors. Corporate bankruptcy is the biggest danger to investor's wealth. Bankruptcy can wipe out the entire equity capital of a firm and can significantly impact its stock prices. In the recent past, giant players in the Indian textile sector have reported financial distress impacting various stakeholders like investors, employees, and practitioners. Therefore, it becomes important to review the financial performance of the traditional textile sector of the economy. To assess the likelihood of bankruptcy of a company, the Altman Z Score model can be employed. This paper attempts to study the probability of failure of selected textile firms. The study further analysis if there is any difference in the bankruptcy score of small, medium, and large-scale companies. Given the volatile sales and earnings of textile manufacturers, there is an indispensable need to assess the financial position of the Indian textile sector. As per the financial stability report of RBI, June 2019, the textile sector has recorded the stressed advance ratio of $16.1 \%$, which means that the textile industry is significantly contributing to stress assets of banks. The main objectives of this empirical study are the following:

1. To predict the $Z$ score of selected textile companies in India using the Altman $Z$ score model.

2. To examine the strength of financial ratios for measuring $Z$ score values.

3. To examine if there exists any significant difference in $z$ scores of selected companies based on their size.

The hypotheses of this empirical study are the following: 
$\mathrm{H} 01$ : There is no significant impact of selected financial ratios on the $z$ score of selected textile companies in India.

$\mathrm{H} 02$ : There is no significant difference in the $\mathrm{z}$ score of selected textile companies in India based on their size.

\section{RESEARCH METHODOLOGY}

This study is based on the secondary financial data of textile companies extracted from the database of Ace analyser and the annual reports of the selected companies. The study is based on the panel data of selected financial ratios of 161 companies for 10-year period from 2009 to 2019 comprising 1,771 data points.

The following tools are used for the analysis of the data:

- Altman Z score Model (1968) is used to predict financial distress of selected companies.

- Correlation and Regression analysis is used to examine the strength of selected financial ratios for measuring $\mathrm{z}$ scores values.

- Median Split is used to categorize firms into large, medium, and small scale based on their total assets.

- Levene Statistics is used to test the homogeneity of variances in z score values.

- Kruskal-Wallis is used to test the significant difference in $\mathrm{Z}$ score values based on the size of the firm.

\section{DATA ANALYSIS AND INTERPRETATION}

This section deals with the data analysis and interpretation.

Figure 1 and table 1 show that on an average 118 out of 161 companies analysed are financially distressed. 37 companies are in the grey area and only 6 companies are financially strong. The analysis shows that only $3.72 \%$ of the selected textile firms are financially strong. The recent government initiatives such as "Make in India", special package to boost exports, technology upgradation fund scheme could prove favourable for the sector and can improve the financial viability of the textile sector soon.

industuria textillă
The table 2 shows that the mean $z$ score value of the textile sector is less than 1.8, therefore it can be said that the overall textile sector is facing distress.

The mean values of the ratios $\mathrm{X} 2$ and $\mathrm{X} 3$ are the lowest. Thus, Retained Earnings/Total Assets and EBIT/ Total assets are the key ratios which are

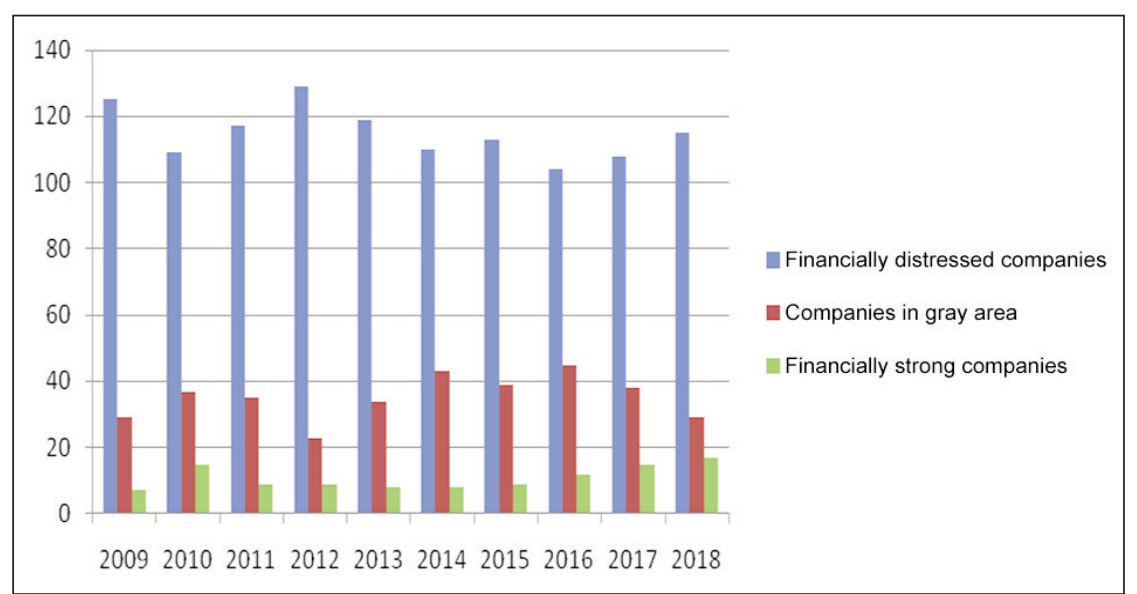

Fig. 1. Z-score Results

\begin{tabular}{|c|c|c|c|c|}
\hline \multicolumn{5}{|c|}{ Z-SCORE RESULTS } \\
\hline Year & $\begin{array}{c}\text { Financially } \\
\text { distressed } \\
\text { companies } \\
(\mathrm{Z} \text { score }<1.8)\end{array}$ & \begin{tabular}{|c|} 
Companies in the \\
grey area \\
(Z score between \\
1.8 and 3$)$
\end{tabular} & $\begin{array}{c}\text { Financially } \\
\text { strong } \\
\text { companies } \\
(Z \text { score }>3)\end{array}$ & Total \\
\hline 2009 & 125 & 29 & 7 & 161 \\
\hline 2010 & 109 & 37 & 15 & 161 \\
\hline 2011 & 117 & 35 & 9 & 161 \\
\hline 2012 & 129 & 23 & 9 & 161 \\
\hline 2013 & 119 & 34 & 8 & 161 \\
\hline 2014 & 110 & 43 & 8 & 161 \\
\hline 2015 & 113 & 39 & 9 & 161 \\
\hline 2016 & 104 & 45 & 12 & 161 \\
\hline 2017 & 108 & 38 & 15 & 161 \\
\hline 2018 & 115 & 29 & 17 & 161 \\
\hline $\begin{array}{l}\text { 10-year } \\
\text { Average }\end{array}$ & 118 & 37 & 6 & 161 \\
\hline
\end{tabular}

Table 2

\begin{tabular}{|c|c|c|c|c|c|}
\hline \multicolumn{7}{|c|}{ DESCRIPTIVE STATISTICS } \\
\hline Indicators & $\mathbf{N}$ & Minimum & Maximum & Mean & Std. deviation \\
\hline z_score & 1771 & -9.91 & 43.39 & 1.3495 & 1.69469 \\
\hline X1 & 1771 & -6.46 & 1.00 & 0.1087 & 0.38885 \\
\hline X2 & 1771 & -1.40 & 8.76 & 0.0093 & 0.24568 \\
\hline X3 & 1771 & -1.03 & 9.08 & 0.0556 & 0.24867 \\
\hline X4 & 1771 & 0.00 & 22.39 & 0.3137 & 1.00934 \\
\hline X5 & 1771 & -0.34 & 6.58 & 0.8353 & 0.60075 \\
\hline $\begin{array}{c}\text { Valid N } \\
\text { (listwise) }\end{array}$ & 1771 & - & - & - & - \\
\hline
\end{tabular}




\begin{tabular}{|c|l|c|c|c|c|c|c|}
\hline \multicolumn{7}{|c|}{ CORRELATION ANALYSIS } \\
\hline \multicolumn{2}{|c|}{ Indicators } & z_score & $\mathbf{X 1}$ & $\mathbf{X 2}$ & $\mathbf{X 3}$ & $\mathbf{X 4}$ & X5 \\
\hline \multirow{3}{*}{ z_score } & Pearson Correlation & 1 & $0.493^{* *}$ & $0.801^{* *}$ & $0.800^{* *}$ & $0.413^{* *}$ & $0.472^{* *}$ \\
\cline { 2 - 9 } & Sig. (2-tailed) & - & 0.000 & 0.000 & 0.000 & 0.000 & 0.000 \\
\cline { 2 - 9 } & $\mathrm{N}$ & 1771 & 1771 & 1771 & 1771 & 1771 & 1771 \\
\hline
\end{tabular}

Note: ${ }^{* *}$ Correlation is significant at the 0.01 level (2-tailed).

contributing to the lower z-score value of the textile sector.

Table 3 shows that $p$-values of all variables are less than 0.05 , therefore the null hypothesis is rejected, and the selected financial ratio has a significant positive relation with $\mathrm{z}$ score.

Tables 4 and 5 show that the p-value of all selected variables is less than 0.05 , therefore the null hypoth-

Table 4

\begin{tabular}{|c|c|c|c|c|}
\hline \multicolumn{5}{|c|}{ REGRESSION ANALYSIS MODEL SUMMARY } \\
\hline Model & $\mathbf{R}$ & $\mathbf{R}$ Square & $\begin{array}{c}\text { Adjusted } \\
\text { R Square }\end{array}$ & $\begin{array}{c}\text { Std. error of } \\
\text { the estimate }\end{array}$ \\
\hline 1 & $1.000^{\mathrm{a}}$ & 1.000 & 1.000 & 0.00000 \\
\hline
\end{tabular}

Note: Predictors: (Constant), X5, X4, X2, X1, X3. statistically significant differences between two or more groups of an independent variable. Table 7 shows the SPSS output of Kruskal Wallis test.

It is evidence from tables 7 and 8 the $p$-value is less than 0.05 , the null hypothesis is rejected and there exists a significant difference in z-score values based on the size of the company. Since the result of the test is significant, a post hoc test is conducted, and the results of the test are given in the table 8 .

Table 9 shows that $z$ score values of small \& large firms and Small \& Medium firms have a statistically significant difference, whereas there is no significant difference in z score values of Large \& Medium firms. Each row tests the null hypothesis that the Sample 1 and Sample 2 distributions are the same. Asymptotic

\begin{tabular}{|c|c|c|c|c|c|}
\hline \multicolumn{7}{|c|}{ Table 5} \\
\hline \multirow{2}{*}{ Model } & Unstandardized coefficients & Standardized coefficients & \multirow{2}{*}{ t } & Sig. \\
\cline { 2 - 6 } & B & Std. error & Beta & -0.003 & 0.998 \\
\hline (Constant) & $-9.442 \mathrm{E}-012$ & 0.000 & - & 236273753.564 & 0.000 \\
\hline X1 & 1.200 & 0.000 & 0.275 & 29616750.193 & 0.000 \\
\hline X2 & 1.400 & 0.000 & 0.203 & 71786600.220 & 0.000 \\
\hline X3 & 3.300 & 0.000 & 0.484 & 375230591.446 & 0.000 \\
\hline X4 & 0.600 & 0.000 & 0.357 & 346256603.116 & 0.000 \\
\hline X5 & 0.999 & 0.000 & 0.354 & & \\
\hline
\end{tabular}

Note: Dependent Variable: z_score.

esis is rejected and all selected financial ratios have a significant impact on $z$ score values.

It is evidence from table 6 the results of Levene statistics shows that the p-value is less than 0.05 , therefore the null hypothesis is rejected and the assumption of homogeneity of variances of one-way ANOVA is violated. Hence, ANOVA cannot be applied to test the significant difference in $z$ score values.

Table 6

\begin{tabular}{|c|c|c|c|}
\hline \multicolumn{4}{|c|}{ HOMOGENEITY OF VARIANCES } \\
\hline Levene statistic & df1 & df2 & Sig. \\
\hline 11.952 & 2 & 1768 & 0.000 \\
\hline
\end{tabular}

The appropriate non-parametric alternate to ANOVA for such data with heterogeneity in variances is the Kruskal-Wallis test which is a rank-based nonparametric test that can be used to determine if there are

\begin{tabular}{|c|c|c|c|}
\hline \multicolumn{4}{|c|}{ KRUSKAL WALLIS TEST RANKS } \\
\hline Indicator & Category & $\mathbf{N}$ & Mean rank \\
\hline \multirow{4}{*}{ z-score } & Large & 616 & 911.73 \\
\cline { 2 - 4 } & Medium & 583 & 921.95 \\
\cline { 2 - 4 } & Small & 572 & 821.65 \\
\cline { 2 - 4 } & Total & 1771 & - \\
\hline
\end{tabular}

\begin{tabular}{|c|c|}
\hline \multicolumn{2}{|c|}{ TEST STATISTICS } \\
\hline Particulars & z_score \\
\hline Chi-Square & 13.503 \\
\hline df & 2 \\
\hline Asymp. Sig. & 0.001 \\
\hline
\end{tabular}




\begin{tabular}{|c|c|c|c|c|c|}
\hline \multicolumn{7}{|c|}{ POST HOC TEST } \\
\hline Sample 1 - Sample 2 & Test statistic & Std. error & Std. test statistic & Sig. & Adj. Sig. \\
\hline Small-Large & 90.081 & 29.689 & 3.034 & 0.002 & 0.007 \\
\hline Small-Medium & 100.300 & 30.091 & 3.333 & 0.001 & 0.003 \\
\hline Large-Medium & -10.219 & 29.543 & -0.346 & 0.729 & 1.000 \\
\hline
\end{tabular}

Table 10

\begin{tabular}{|c|c|c|}
\hline \multicolumn{3}{|c|}{ CATEGORY WISE DESCRIPTIVE STATISTICS } \\
OF Z SCORE \\
\hline Category & Median & $\mathbf{N}$ \\
\hline Large & 1.3756 & 616 \\
\hline Medium & 1.3793 & 583 \\
\hline Small & 1.2072 & 572 \\
\hline Total & 1.3400 & 1771 \\
\hline
\end{tabular}

significances (2-sided testes) are displayed. The significance level is 0.05 .

From table 10, it can be seen that small companies have a lower average $z$ score compared to large and medium companies.

\section{FINDING AND CONCLUSIONS}

The study analysed the selected financial ratios and $Z$ score values of listed textile companies in India. The following aspects represent the most important findings of this empirical study:

- Based on a 10 -year average z score, only $3.72 \%$ of the selected companies are financially strong and most of the companies are in danger zone.

- The results of descriptive statistics show that the two ratios i.e., Retained Earnings/Total Assets and EBIT/Total assets contribute to the lower z-score value of the textile sector.

- The correlation and regression output show that selected five financial ratios of the Altman Model have a significant impact on $Z$ score values. It means that these ratios have significant power to predict bankruptcy.

- Kruskal and Wallis test show that there exists a significant difference in Z score values of Large, Medium, and Small-scale companies. The smallscale companies have a lower $z$ score compared to large and medium companies which means that these companies have higher financial distress.

This study shows that majority of the companies in the Indian textile sector are facing financial distress. Altman $\mathrm{Z}$ score model has the predictive power to predict the financial unsoundness before the company realizes or declares bankruptcy. It is therefore recommended to all stakeholders in general and investors to employ the $Z$ score model before investing.

This research will enable the researchers to understand the bankruptcy profile of the Indian textile sector and the role played by different financial indicators in causing bankruptcy. Furthermore, the findings of this study will also help the investors and practitioners associated with the textile industry to adopt more specific techniques to predict bankruptcy.

The current research has applied only Altman Z score to predict bankruptcy. Further studies can be done in the textile sector using logit and probit analysis or other bankruptcy models. Also, a comprehensive study can be conducted comparing the financial distress of varied sectors in the Indian context.

\section{REFERENCES}

[1] Altman, E.I., Financial ratios, discriminant analysis, and the prediction of corporate bankruptcy, In: The Journal of Finance, 1968, 23, 4, 589-609

[2] Beaver, W.H., Financial ratios as predictors of failure, In: Journal of Accounting Research, 1966, 71-111

[3] Spulbar, C., Trivedi, J., Birau, R. Investigating abnormal volatility transmission patterns between emerging and developed stock markets: a case study, In: Journal of Business Economics and Management, 2020, 21, 6, 1561-1592, https://doi.org/10.3846/jbem.2020.13507.

[4] Spulbar, C., Birau, R., Emerging research on monetary policy, banking, and financial markets, IGI Global, USA, 2019, https://doi.org/10.4018/978-1-5225-9269-3

[5] Grice, J.S., Ingram, R.W., Tests of the generalizability of Altman's bankruptcy prediction model, In: Journal of Business Research, 2001, 54, 1, 53-61

[6] Agarwal, V., Taffler, R., Comparing the performance of market-based and accounting-based bankruptcy prediction models, In: Journal of Banking \& Finance, 2008, 32, 8, 1541-1551

[7] Batchelor, T., Corporate Bankruptcy: Testing the Efficacy of the Altman Z-Score, In: International Research Journal of Applied Finance, 2018, 9, 9, 404-414

[8] Ullal, M.S., Spulbar, C., Hawaldar, I.T., Popescu, V., Birau, R., The impact of online reviews on e-commerce sales in India: a case study, In: Economic Research-Ekonomska Istraživanja, 2021, DOI: 10.1080/1331677X.2020. 1865179, https://www.tandfonline.com/doi/full/10.1080/1331677X.2020.1865179.

[9] Springate, G.L., Predicting the Possibility of Failure in a Canadian Firms, Research Project, January, Simon Fraser University, Canada, 1978 
[10] Fulmer, J.G. Jr., Moon, J.E., Gavin, T.A., Erwin, M.J., A bankruptcy classification model for small firms, In: Journal of Commercial Bank Landing, 1984, 25-37

[11] Ohlson, J.A., Financial ratios and the probabilistic prediction of bankruptcy, In: Journal of Accounting Research, 1980, 109-131

[12] Campbell, J.Y., Hilscher, J., Szilagyi, J., In search of distress risk, In: The Journal of Finance, 2008, 63, 6, 2899-2939

[13] Sun, J., Li, H., Huang, Q.H., He, K.Y., Predicting financial distress and corporate failure: A review from the stateof-the-art definitions, modeling, sampling, and featuring approaches, In: Knowledge-Based Systems, 2014, 57, $41-56$

[14] Jones, S., Johnstone, D., Wilson, R., Predicting corporate bankruptcy: An evaluation of alternative statistical frameworks, In: Journal of Business Finance \& Accounting, 2017, 44, 1-2, 3-34

[15] Zmijewski, M.E., Methodological issues related to the estimation of financial distress prediction models, In: Journal of Accounting Research, 1984, 59-82

[16] Wu, Y., Gaunt, C., Gray, S., A comparison of alternative bankruptcy prediction models, In: Journal of Contemporary Accounting \& Economics, 2010, 6, 1, 34-45

[17] Meher, B.K., Puntambekar, G.L., Hawaldar, I.T., Spulbar, C., Birau, R., Rebegea, C., An Effectiveness Assessment of Preventive Management Strategies in order to Manage Non Performing Assets in Indian banks: A Case Study, In: Scientific Annals of Economics and Business, 2020, 67, 2, 235-258, http://saeb.feaa.uaic.ro/index.php/ saeb/article/view/1026

[18] Mehdiabadi, A., Tabatabeinasab, M., Spulbar, C., Karbassi Yazdi, A., Birau, R., Are We Ready for the Challenge of Banks 4.0? Designing a Roadmap for Banking Systems in Industry 4.0., In: International Journal of Financial Studies, Special Issue "The Financial Industry 4.0", 2020, 8, 2, 32, https://doi.org/10.3390/ijfs8020032

[19] Meher, B.K., Thonse, H.I., Latasha, M., Spulbar, C.M., Birau, F.R., Rebegea, C., The Impact of Digital Banking on the Growth of Micro, Small and Medium Enterprises (MSMES) in India: A Case Study, In: Business: Theory and Practice, 2021, 22, 1, 18-28, https://doi.org/10.3846/btp.2021.12856, Available at SSRN: https://ssrn.com/ abstract $=3770889$ [Accessed on January 2021]

[20] Bandyopadhyay, A., Predicting the probability of default of Indian corporate bonds: logistic and Z-score model approaches, In: The Journal of Risk Finance, 2006, 7, 3, 255-272

[21] Mishra, S., Credit Risk Evaluation of BSE 200 Manufacturing Companies Using a Z-Score Model, In: IPE Journal of Management, 2013, 3, 1, 1

[22] Patanwala, A., A Prediction of the Financial Distress of the Major Players in the FMCG Sector Using Revised Altman Z-Score Model and Liquidity Ratios, In: Business Sciences International Research Journal, 2017, 4, 1, $77-82$

[23] Sanesh, C., The analytical study of Altman Z score on NIFTY 50 Companies, In: IRA-International Journal of Management \& Social Sciences, ISSN 2455-2267, 2016, 3, 3

[24] Malik, M.S., Awais, M., Timsal, A., Hayat, F., Z-Score Model: Analysis and Implication on Textile Sector of Pakistan, In: International Journal of Academic Research, 2016, 4, 2, 140-158

[25] Archana, H.N., Default Prediction using Altman Z Score Model-A Study of some Select Retail Firms, In: Sumedha Journal of Management, 2018, 7, 4, 60-75

[26] Altman, E.I., Predicting financial distress of companies: Revisiting the Z-score and ZETA models. In: Stern School of Business, New York University, 2000, 9-12

\section{Authors:}

RASHMI RUPESH SONI ${ }^{1}$, IQBAL THONSE HAWALDAR ${ }^{2}$, ANJU SUNNY VASWANI ${ }^{3}$, CRISTI SPULBAR $^{4}$ RAMONA BIRAU ${ }^{5}$, ELENA LOREDANA MINEA ${ }^{4}$, SUHAN MENDON ${ }^{6}$, MARIA MAGDALENA CRIVEANU $^{4}$

${ }^{1} \mathrm{~K}$ J Somaiya Institute of Management Studies \& Research, Mumbai, India e-mail: rashmi.soni@somaiya.edu

${ }^{2}$ Department of Accounting \& Finance, College of Business Administration, Kingdom University, Bahrain e-mail: thiqbal34@gmail.com

${ }^{3}$ H. \& G.H. Mansukhani Institute of Management, Ulhasnagar, India e-mail: sawlanianjali@gmail.com

\footnotetext{
${ }^{4}$ University of Craiova, Faculty of Economics and Business Administration Craiova, Romania e-mail: cristi_spulbar@yahoo.com, loredanaelenaminea@gmail.com, magda.criveanu@yahoo.com
}

${ }^{5} \mathrm{C}$-tin Brancusi University of Targu Jiu, Faculty of Education Science, Law and Public Administration, Romania

${ }^{6}$ Manipal Institute of Management, MAHE (Deemed to be University) Manipal, India

e-mail: suhan.mendon@manipal.edu

\section{Corresponding author:}

RAMONA BIRAU

e-mail: ramona.f.birau@gmail.com 